\title{
Evaluation of Wheat (Triticum aestivum L.) Genotypes for Changing Climatic Condition under Different Sowing Windows in Semi-Arid Tropics of Western Maharashtra, India
}

\author{
D.N. Bankar, V.S. Baviskar* , K.J. Yashavantha Kumar, S.S. Raskar, \\ S.S. Khairnar, V.D. Gite, V.D. Surve, J.H. Bagwan and B.K. Honrao
}

Genetics and Plant Breeding Group, MACS-Agharkar Research Institute, G. G. Agarkar Road, Pune-411004, Maharashtra, India

*Corresponding author

\begin{tabular}{|l|}
\hline K e y w o r d s \\
$\begin{array}{l}\text { Sowing window, } \\
\text { Genotype, Date of } \\
\text { sowing, Yield, } \\
\text { Wheat }\end{array}$ \\
\hline Article Info \\
\hline $\begin{array}{l}\text { Accepted: } \\
\text { 07 March } 2018 \\
\text { Available Online: } \\
\text { 10 April } 2018\end{array}$ \\
\hline
\end{tabular}

Keywords

Sowing window, Genotype, Date of sowing, Yield,

Whea

\section{Accepted:}

Available Online:

10 April 2018

\section{A B S T R A C T}

A field experiment was conducted to study the performance of five wheat (Triticum aestivum L.) genotypes at two different sowing windows under irrigated condition during rabi season of 2016-2017 in Peninsular Zone at Experimental Research Farm, MACSAgharkar Research Institute, Pune (MS).The experiment was laid out in a split plot design with three replications. The treatment consists of five wheat genotypes viz. DBW 168, MACS 6478, MACS 6222, GW 322 and UAS 304, were sown during two sowing windows, as timely (45 SMW) and late (48 SMW).Statistical analysis revealed that effect of sowing dates was found significant on days to heading, days to maturity, plant height, spikelets spike $^{-1}$, effective tillersmeter ${ }^{-2}$, grains spike ${ }^{-1}$, harvest index. However, effect of various genotypes was also found significant on all traits except spikelets spike ${ }^{-1}$. In case of interaction effect of sowing windows and genotypes, the days to heading, days to maturity, plant height and grains spike ${ }^{-1}$ were found significant. Due to favorable climate, the timely sown wheat was shown highest grain yield $\left(54.93 \mathrm{qha}^{-1}\right)$ over late sown wheat $\left(50.86 \mathrm{qha}^{-1}\right)$ and the percent increase was $8 \%$. Whereas, among different genotypes, the higher grain yield (57.45 $\mathrm{qha}^{-1}$ ) was recorded by MACS 6478, which was found at par with GW $322\left(54.90 \mathrm{qha}^{-1}\right)$ and significantly superior to remaining three genotypes UAS 304, MACS 6222 and DBW 168. On mean basis, in timely and late sown condition, the MACS 6478 produced maximum grain yield (59.16 and $55.74 \mathrm{qha}^{-1}$, respectively) compared to rest of genotypes. Whereas, all the growth, yield attributes and yield were found maximum under timely sown condition over late sown condition in peninsular zone.

\section{Introduction}

Wheat (Triticum aestivum L.) belongs to family Poaceae and is very important crop as it contributes major portion of staple food for world's population and provides more calories and protein in the world's diet than any other cereal (CIMMYT, 2002). Wheat is the second important food crop after rice in terms of both area and production in India. In India, during 2015-16 the area under wheat cultivation was 30.23 mha with an average productivity of $30.93 \mathrm{q} \mathrm{ha}^{-1}$. In Maharashtra, it occupies an area of 6.29 lakh ha with an average 
productivity of $12.05 \mathrm{q} \mathrm{ha}^{-1}$ (DES, MoA and FW, India 2015-16). In peninsular zone, sowing of wheat is done in first week of November to late December. The important reasons for low productivity in India are delayed sowing, aberrant weather conditions, weed infestation, inadequate use of balanced fertilizers and improper irrigation schedule.

Time of sowing is important as sowing date could be adjusted so crop can escape from period of high humidity combined with high temperature (Wall, 1991) so sowing time significantly influences growth and yield attributes of wheat crop. Selection of crop cultivar is also important factor in production as the wheat cultivars could not perform equally in timely and late sowing condition, Singh et al., (1998). In late planting, the wheat variety should be short duration that may escape from high temperature at the grain filling stage (Phadnawis and Saini, 1992). Ansary et al., (1989) reported that delay sowing suppressed the yield, caused by reduction in the yield contributing traits like number of tillers, number of grains spike ${ }^{-1}$, and grain yield. Rajput and Verma (1994) observed that normal sowing gave higher grain yield than late sowing.

To minimize the adverse effect of temperature by adjusting sowing time to an optimum sowing window and to find out heat tolerant genotypes, which are suitable for changing climatic conditions to ensure high grain yield.

The newly developed varieties need to be evaluated for their agronomic performance under different environmental conditions. Therefore, the present study was undertaken to evaluate the performance of new wheat genotypes under different sowing windows to find out the suitable genotype for optimum and late sown condition, heat tolerant and heat sensitive genotype and optimum sowing time for a specific genotype.

\section{Materials and Methods}

An experiment was conducted at Experimental Research Farm, MACS-Agharkar Research Institute, Pune (MS), during rabi-season 201617. This is one of the main coordinating Centre of All India Coordinated Research Project on Wheat (ICAR) in Peninsular Zone of India.

\section{Experimental site}

The experimental farm is located at $18^{0} 04^{\prime} \mathrm{N}$; $74^{0} 21$ 'E; $549 \mathrm{~m}$ above mean sea level at Hol, Baramati, Pune district, India. It falls under the agro ecological region Deccan Plateau, hot and semi-arid climate (AER-6) and agro climatic Zone AZ-95 i.e. scarcity zone of Maharashtra. The long term average annual rainfall is $560 \mathrm{~mm}$ and this is restricted to south west and retreating monsoon.

\section{Climate}

The average weather parameters during cropping period at experimental site were maximum temperatures $31.5^{\circ} \mathrm{C}$ and minimum temperature was $11.8^{0} \mathrm{C}$, minimum relative humidity $38.4 \%$ and maximum was $88.2 \%$ (Fig. 1).

\section{Soil characteristics}

The experimental soil was black cotton with silt $48.8 \%$, sand $9.6 \%$, clay $24.2 \%$, bulk density $1.38 \mathrm{Mg} \mathrm{m}^{-3}$, organic carbon $0.9 \%$, available nitrogen, phosphorus and potash were $216,7.61$ and $284 \mathrm{~kg} \mathrm{ha}^{-1}$, respectively. However, the soil $\mathrm{pH}$ and EC were 7.83 and 0.77 , respectively (Table 1 ).

\section{Treatment}

The experiment was laid out in split plot design with three replications. The main plot treatment comprising of two sowing windows 
namely normal (i.e. during $45^{\text {th }}$ SMW) and late (i.e. during $48^{\text {th }} \mathrm{SMW}$ ). Whereas, the sub plot treatments were five bread wheat genotypes viz., DBW 168, GW 322, MACS 6222, MACS 6478 and UAS 304. Total area of the subplot was $14.40 \mathrm{~m}^{2}$, each subplot consists 9 rows of $8 \mathrm{~m}$ length and $20 \mathrm{~cm}$ spacing between two rows.

At maturity, two outer rows for each plot, 50 $\mathrm{cm}$ from each end of the plots were left as borders and the middle 7 rows were harvested. The recommended agronomic practices were followed for good crop and competitive crop stand.

The crop was fertilized with 120:60:40 kg NPK ha ${ }^{-1}$ out of which $40 \mathrm{~kg} \mathrm{~N}, 60 \mathrm{~kg} \mathrm{P}_{2} \mathrm{O}_{5}$ and $40 \mathrm{~kg} \mathrm{~K}_{2} \mathrm{O}$ was applied as basal dose and the remaining $80 \mathrm{~kg} \mathrm{~N}$ was given as top dressing in two splits i.e. half at first irrigation (21-25 DAS) and half at second irrigation (4042 DAS).

The yield parameters and yields were recorded and analyzed with Statistical Tool for Agricultural Research (STAR) software (IRRI).

\section{Sampling and data recording}

The data were recorded during the experiment viz. days to heading, days to maturity, plant height, effective tillers $\mathrm{m}^{-2}$, grains spike $^{-1}$, spike length, spikelets spike ${ }^{-1}$, thousand grain weight, biomass and grain yield.

For recording effective tillers $\mathrm{m}^{-2}$ a quadrate was marked in one square meter area and measured number of productive tillers.

For recording characters such as spike length, spikelets and grains spike ${ }^{-1}$, ten random spikes were harvested from each subplot. Thousand grain weights were calculated by counting 1000 grain from harvested grain yield.

\section{Results and Discussion}

\section{Effect on growth attributes}

\section{Days to heading}

Data regarding days to heading are presented in Table 3. Statistical analysis of the days to heading indicated that the differences among wheat genotypes were significant. Sowing during $45^{\text {th }}$ SMW headed 4 days later than wheat sown during $48^{\text {th }}$ SMW. Among genotypes, mean of the data revealed that maximum days to heading were taken by genotype DBW 168, followed by genotype MACS 6478.

Minimum days to heading were taken by MACS 6222. Keeping the results of days to heading of all genotypes these can be ranked as early MACS 6222, GW 322, UAS 304 and late DBW 168 and MACS 6478.The interaction effect of sowing windows and genotypes was also found significant (Table $2)$. These results are line up with the results of Wajid et al., (2006).

\section{Days to maturity}

Effect of sowing windows was found significant to maturity days (Table 2). $45^{\text {th }}$ SMW sown wheat matured 5 days later than $48^{\text {th }}$ SMW sown. Delayed sowing significantly decrease days to maturity similar results such as gradually decreasing days to maturity have been reported by Connor et al., (1992); Dokuyucu et al., (2004). The genotype of wheat had significant effect on days to maturity, among the varieties MACS 6222 and GW 322 (106.67) was found early and DBW 168(110.33) was late (Table 3). Average days required for maturity was 108days, which ranged from 104 to 113 days (Table 2). Interaction effect of sowing windows and genotypes was significant at 5\% level of significance (Table 2). 


\section{Plant height (cm)}

The statistical analysis of data indicated that sowing windows, genotypes and interaction of both had significant effect on plant height (Table 2) these results are line up with Shahzad et al., (2007) state that height of the crop is mainly controlled by the genetic diversity of a genotype and it can also be affected by the environmental factors. Plant height was reduced in $48^{\text {th }}$ SMW sown $(90.73 \mathrm{~cm})$ than $45^{\text {th }}$ SMW sown $(98 \mathrm{~cm})$.

Genotype was significant for plant height these results were line up with results of Vahid et al., (2010) stated that cultivars were significantly different for plant height also cultivar and sowing date interaction was significant for plant height. UAS $304(99 \mathrm{~cm})$ produce taller plant and MACS 6478 (91.67) shorter, average plant height observed was $94.37 \mathrm{~cm}$ (Table 3), these different could be due to genotypic differences among the genotypes.

\section{Spike length (cm)}

Statistically the effect of genotypes was found to be significant for spike length (Table 2) these results are similar to those of Vahid et al., (2010). The average spike length was 9.67 $\mathrm{cm}$ which ranged from 8 to $12 \mathrm{~cm}$. The spike length was shortest in DBW $168(8.83 \mathrm{~cm})$ and longest in MACS 6478(10.50 cm), followed by MACS 6222(10.17 cm) and UAS $304(9.50 \mathrm{~cm})$ (Table 3).

\section{Spikelets spike ${ }^{-1}$}

The average spikelet spike ${ }^{-1}$ was 19.10 which ranged from 17 to 21(Table 3), Sowing window has significant effect and genotype had no significant effect on spikelets spike ${ }^{-1}$ (Table 2). Spikelet spike ${ }^{-1}$ was higher in $45^{\text {th }}$ SMW (19.60) than $48^{\text {th }}$ SMW (18.60) (Table $3)$. These results were similar to those of
Hossain et al., 2017. Spikelets spike ${ }^{-1}$ was lowest in varieties GW 322(18.83), UAS 304(18.83) and highest in MACS 6222 (19.33), MACS 6478(19.33), DBW 168(19.17).

\section{Effect on yield attributes and yield}

\section{Effective tillers meter ${ }^{-2}$}

Effect of sowing window was found significant for effective tillers meter ${ }^{-2}$ (Table 2).The average number of effective tillers meter $^{-2}$ was 343 which ranged from 240 to 410 (Table 3). Effective tillers meter ${ }^{-2}$ of $45^{\text {th }} \mathrm{SMW}$ (366) sown was found comparatively higher than $48^{\text {th }}$ SMW (320) sown (Table 3).

These results are according to those of Dokuyucu et al., (2004), Vahid et al., (2010) observed that delayed sowing decreased the number of effective tiller per plant.

The genotypes of wheat had significant effect on effective tillers meter ${ }^{-2}$ (Table 2). The effective tillers meter ${ }^{-2}$ of UAS 304 genotype was found lowest (309) and GW 322 (333) than genotypes MACS 6478 (369), MACS 6222 (353) and DBW 168 (351). These results are in accordance with those of Aslam et al., (2003), Khaliq (2004) and Wajid et al., (2006), stated that differences in number of tillers per square meter among varieties might be attributed to their genetic diversity.

\section{Grains spike $^{-1}$}

The average number of grains spike $^{-1}$ was 48.70, which was ranged from 29 to 67 (Table 3 ). Statistically effect of sowing windows, genotypes and interaction effect of sowing window and genotype had significant effect on number of grains spike ${ }^{-1}$ (Table 2). Number of grains spike $^{-1}$ is an important yield contributing parameter and has a direct effect on the final grain yield of wheat. 
Table.1 Soil characteristics of the experimental field situated at research farm of Agharkar Research Institute, Pune

\begin{tabular}{|c|c|c|}
\hline Sr. No. & Soil Characteristics & Soil type/ Value \\
\hline 1 & Soil group & Black cotton soil \\
\hline 2 & Sand $(\%)$ & 9.6 \\
\hline 3 & Silt (\%) & 48.8 \\
\hline 4 & Clay (\%) & 24.2 \\
\hline 5 & Bulk density, $\mathrm{Mg} \mathrm{m}^{-3}$ & 1.38 \\
\hline 6 & Organic carbon, $(\%)$ & 0.9 \\
\hline 7 & Available N, kg ha ${ }^{-1}$ & 216 \\
\hline 8 & Available $\mathrm{P}_{2} \mathrm{O}_{5}, \mathrm{~kg} \mathrm{ha}^{-1}$ & 7.61 \\
\hline 9 & Available $\mathrm{K}_{2} \mathrm{O}, \mathrm{kg} \mathrm{ha}^{-1}$ & 284 \\
\hline 10 & $\mathrm{pH}(1: 2)$ & 7.83 \\
\hline 11 & $\mathrm{EC}(1: 2)$ & 0.77 \\
\hline 12 & $\mathrm{Na}$ (Me/lit.) & 0.86 \\
\hline 13 & Calcium (\%) & 16.8 \\
\hline 14 & Iron (ppm) & 4.7 \\
\hline 15 & Magnesium (ppm) & 0.69 \\
\hline 16 & Zinc (ppm) & 1.31 \\
\hline 17 & Copper (ppm) & 0.99 \\
\hline
\end{tabular}


Table.2 Analysis of variance (ANOVA) for growth, yield and yield attributes of wheat under different Sowing windows and wheat genotypes

\begin{tabular}{|c|c|c|c|c|c|c|c|c|c|c|c|}
\hline SOURCE & df & $\begin{array}{c}\text { DH } \\
\text { (Days) }\end{array}$ & $\begin{array}{c}\text { DM } \\
\text { (Days) }\end{array}$ & $\begin{array}{l}\text { PH } \\
(\mathrm{cm})\end{array}$ & SL/Sp. & $\mathrm{ET} / \mathrm{m}^{2}$ & Gr./Sp. & $\begin{array}{c}\text { TGW } \\
(\mathrm{g})\end{array}$ & $\begin{array}{c}\text { Biomass } \\
\text { (g/ha) }\end{array}$ & $\begin{array}{c}\text { Gr. Yld. } \\
\text { (q/ha) }\end{array}$ & HI \% \\
\hline REP & 2 & 1.03 & 1.03 & 7.43 & 0.30 & 332.50 & 15.60 & 3.03 & 416.28 & 45.18 & 2.81 \\
\hline Sowing window & 1 & $90.13^{*}$ & $154.13 * *$ & $396.03 * *$ & $7.50^{*}$ & $15870 *$ & $1809.63 * *$ & NS & NS & NS & $22.77 *$ \\
\hline Error(a) & 2 & 1.43 & 0.23 & 1.03 & 0.10 & 167.50 & 12.13 & 3.23 & 88.62 & 16.81 & 0.61 \\
\hline CV (a) $\%$ & & 1.76 & 0.45 & 1.08 & 1.66 & 3.77 & 7.15 & 4.38 & 6.82 & 7.75 & 2.03 \\
\hline LSD & & 1.83 & 1.76 & 3.56 & 0.49 & 20.33 & 6.03 & NS & NS & NS & 1.22 \\
\hline Genotypes & 4 & $49.21 * *$ & $18.20 * *$ & $48.53 * *$ & 0.38 & $3111.66^{*}$ & $174.36 * *$ & $28.53 * *$ & $306.58 *$ & $59.63 * *$ & $42.24 * *$ \\
\hline DOS : Genotypes & 4 & $3.38 *$ & $4.46 *$ & $26.03 * *$ & NS & NS & $72.80 * *$ & NS & NS & NS & NS \\
\hline Error (b) & 16 & 1.02 & 1.25 & 5.10 & 0.61 & 778.12 & 12.28 & 3.42 & 80.42 & 10.49 & 7.00 \\
\hline CV (b)\% & & 1.49 & 1.04 & 2.40 & 4.11 & 8.13 & 7.20 & 4.51 & 6.49 & 6.12 & 6.88 \\
\hline LSD & & 1.75 & 1.94 & 3.91 & NS & 34.14 & 6.06 & 2.26 & 10.97 & 3.96 & 3.23 \\
\hline Mean & & 67.93 & 108.13 & 94.37 & 19.10 & 343.00 & 48.70 & 41.03 & 138.10 & 52.89 & 38.44 \\
\hline
\end{tabular}

(DH: Days to heading; DM: Days to maturity, PH: Plant height, SL/SP: Spikelets spike ${ }^{-1}$; ET/m²: Effective tillers $\mathrm{m}^{-2}$; GR/SP: Grain spike ${ }^{-1}$; TGW: Thousand grain weight; Biomass: Biomass/ha; Gr. Yld.: Grain yield and HI: Harvest Index; *: Significant at 5\%; **: Significant at 1\%; NS: Non-significant)

Table.3 Effect of various sowing windows and genotypes on growth, yield attributes and yield of wheat under Semi-arid tropics of Western Maharashtra

\begin{tabular}{|c|c|c|c|c|c|c|c|c|c|c|c|}
\hline Treatment & $\begin{array}{c}\text { DH } \\
\text { (Days) }\end{array}$ & $\begin{array}{c}\text { DM } \\
\text { (Days) }\end{array}$ & $\begin{array}{l}\text { PH } \\
(\mathrm{cm})\end{array}$ & $\begin{array}{c}\text { SPKL } \\
(\mathrm{cm})\end{array}$ & SL/Sp. & $\mathrm{ETT} / \mathrm{m}^{2}$ & Gr./Sp. & $\begin{array}{l}\text { TGW } \\
\text { (g) }\end{array}$ & $\begin{array}{c}\text { Biomass } \\
(\mathrm{g} / \mathrm{ha})\end{array}$ & $\begin{array}{l}\text { Gr. Yld. } \\
\text { (g/ha) }\end{array}$ & HI \% \\
\hline \multicolumn{12}{|l|}{ Sowing window (MP) } \\
\hline Normal $\left(45^{\text {th }}\right.$ SMW) & 69.67 & 110.40 & 98.00 & 10.0 & 19.60 & 366 & 56.47 & 42.00 & 140.46 & 54.93 & 39.31 \\
\hline Late $\left(48^{\text {th }}\right.$ SMW) & 66.20 & 105.87 & 90.73 & 9.30 & 18.60 & 320 & 40.93 & 40.07 & 135.75 & 50.86 & 37.56 \\
\hline LSD for MP & 1.83 & 1.76 & 3.56 & NS & 0.49 & 20.33 & 6.03 & NS & NS & NS & 1.22 \\
\hline \multicolumn{12}{|l|}{ Genotypes (SP) } \\
\hline DBW 168 & 72.67 & 110.33 & 93.67 & 8.80 & 19.17 & 351 & 48.33 & 41.67 & 146.82 & 50.40 & 34.33 \\
\hline GW 322 & 66.33 & 106.67 & 94.83 & 9.30 & 18.83 & 333 & 50.33 & 37.67 & 136.19 & 54.90 & 40.42 \\
\hline MACS 6222 & 65.50 & 106.67 & 92.67 & 10.20 & 19.33 & 353 & 56.67 & 43.00 & 127.49 & 50.40 & 39.57 \\
\hline MACS 6478 & 68.50 & 107.33 & 91.67 & 10.50 & 19.33 & 369 & 42.17 & 42.67 & 141.55 & 57.45 & 40.58 \\
\hline UAS 304 & 66.67 & 109.67 & 99.00 & 9.50 & 18.83 & 309 & 46.00 & 40.17 & 138.49 & 51.31 & 37.29 \\
\hline LSD for SP & 1.75 & 1.94 & 3.91 & 0.90 & NS & 34.14 & 6.06 & 2.26 & 10.97 & 3.96 & 3.23 \\
\hline Grand Mean & 67.93 & 108.13 & 94.37 & 9.70 & 19.10 & 343 & 48.70 & 41.03 & 138.11 & 52.89 & 38.44 \\
\hline Range & $62-74$ & $104-113$ & $86-107$ & $8-12$ & $17-21$ & $240-410$ & $29-67$ & $33-45$ & $111.53-158.88$ & $40.55-63.65$ & $29.74-43.77$ \\
\hline
\end{tabular}

(Gr.Yld.: Grain yield; DH: Days to heading; DM: Days to maturity, PH: Plant height, SL/SP: Spikelets spike ${ }^{-1}$ :ET/m ${ }^{2}$ : Effective tillers $\mathrm{m}^{-2}$, GR/SP:Grainspike ${ }^{-1}$; TGW: Thousand grain weight; and HI: Harvest index; SMW: Standard Meteorological Week) 
Table.4 Mean comparison of various sowing windows and genotypes for grain and biomass yield and harvest index of wheat

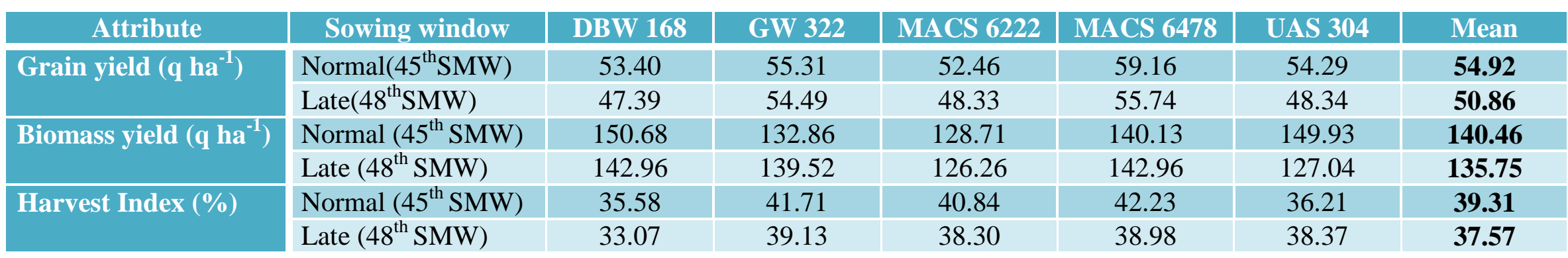

SMW: Standard Meteorological Week

Fig.1 Weekly average temperature, humidity and rainfall during crop growth period (November 2016 to March 2017

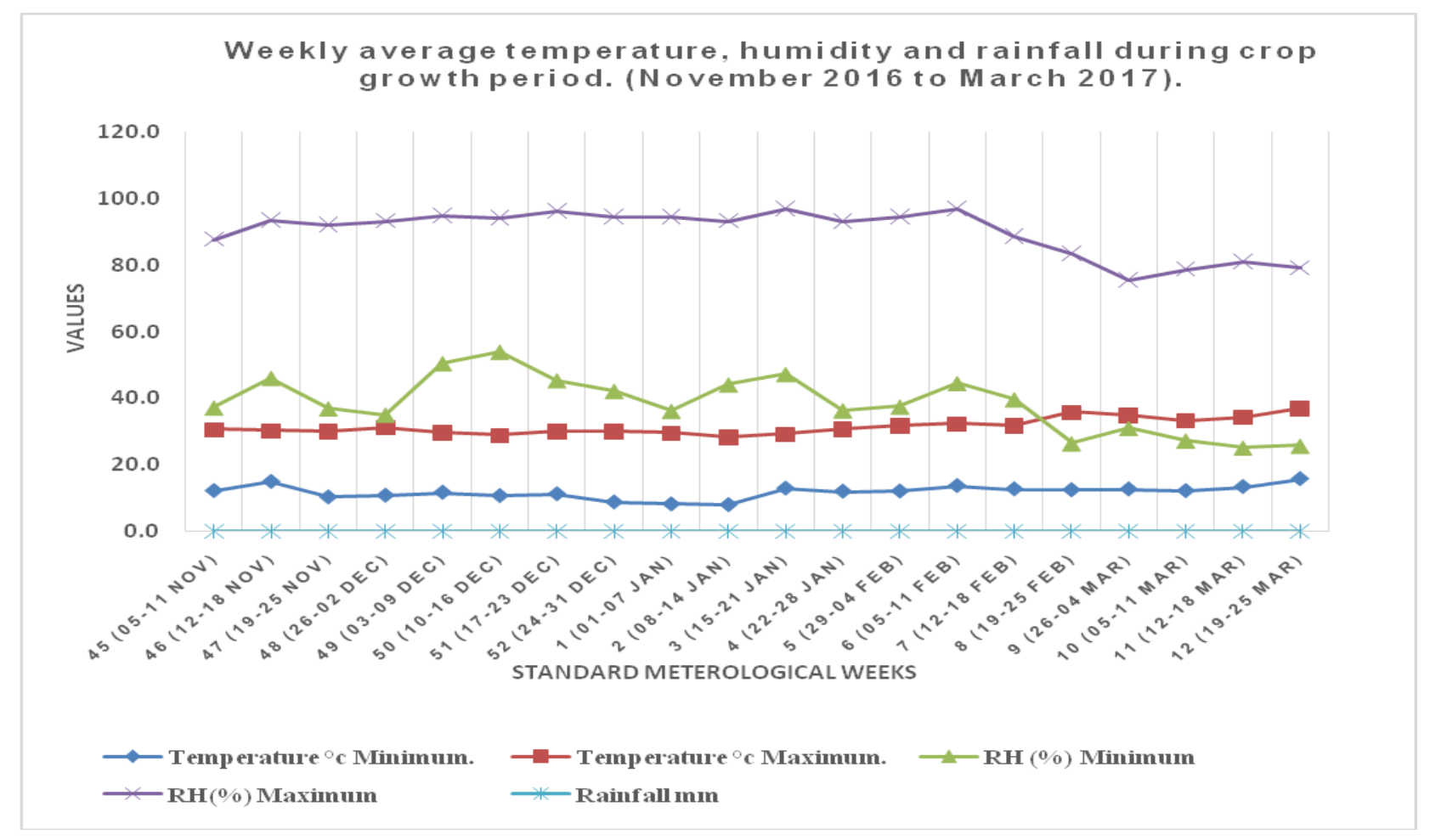


Grains spike $e^{-1}$ of $45^{\text {th }}$ SMW (56.47) was found comparatively higher than $48^{\text {th }}$ SMW (40.93) (Table 3), these results are accordance of Shahzad et al., (2002), Tahir et al., (2009) stated that less number of grains spike ${ }^{-1}$ in late sowing was due to less production of photosynthates due to shorter growing period. Among the genotypes MACS 6222(56.67) produced significantly more number of grains spike $^{-1}$ followed by GW 322(50.33).

\section{Thousand grain weight $(\mathrm{g})$}

Genotypes had significant effect on thousandgrain weight. The average thousand grain weight $41.03 \mathrm{~g}$ which was ranged from 33 to $45 \mathrm{~g}$, among the Genotypes MACS 6222(43g) produced maximum thousand grain weight which is statistically at par with MACS 6478 $(42.67 \mathrm{~g})$, minimum thousand grain weight (37.67 g) was produced by GW 322 (Table 3). Delay the sowing of wheat decreased the thousand-grain weight similar results were line up with Marasini et al., (2016).

\section{Biomass yield (q ha $\left.{ }^{-1}\right)$}

Genotypes had significant effect on biomass of wheat (Table 2). The average biomass was $138.10 \mathrm{qha}^{-1}$. The biomass was found highest in Genotype DBW 168(146.82 qha $\left.^{-1}\right)$ which was at par with MACS 6478(141.55 $\left.\mathrm{qha}^{-1}\right)$ followed by UAS 304(138.49 $\left.\mathrm{qha}^{-1}\right)$, GW 322 (136.19 $\left.\mathrm{qha}^{-1}\right)$ and MACS 6222(127.49 qha $^{-1}$ ) (Table 4).

Higher straw yield in DBW 168 and MACS 6478 can be attributed to more number of tillers $\mathrm{m}^{-2}$ and more plant height; these results are similar with those of Matuz and Aziz (1990).Higher straw yield in early sowing was mainly due to more number of tillers $\mathrm{m}^{-2}$ and more plant height Donaldson et al., (2001), they were reported that early sowing resulted in higher straw yield due to more number of tillers.

\section{Grain yield $\left(\mathbf{q} \mathbf{h a}^{-1}\right)$}

Sowing window had non-significant effect on grain yield but wheat sown during $45^{\text {th }} \mathrm{SMW}$ $\left(54.93 \mathrm{qha}^{-1}\right)$ produces higher grain yield than sown during $48^{\text {th }}$ SMW $\left(50.86 \mathrm{q} \mathrm{ha}^{-1}\right.$ ) (Table 3 ) and the percent increase was $8 \%$, these results were reported earlier by Vahid et al., (2010). Decrease in the grain yield was due lower the effective tillers merter ${ }^{-2}$, less grain spike $^{-1}$, low thousand grain weight, these results were similar to those of Spink et al., (2000), Aslam et al., (2003) and Tahir et al., (2009). Statistical analysis revealed that genotypes had significant effect on grain yield (Table 2). The average grain yield was $52.89 \mathrm{qha}^{-1}$, which ranges from 40.55 to 63.65 $\mathrm{qha}^{-1}$ (Table 3). The higher grain yield (57.45 $\mathrm{qha}^{-1}$ ) was recorded by MACS 6478, which was found at par with GW 322 (54.90 $\left.\mathrm{qha}^{-1}\right)$ and significantly superior to remaining three genotypes UAS 304, MACS 6222 and DBW 168 (Table 3). On mean basis, under timely and late sown condition, the MACS 6478 produced maximum grain yield (59.16 and $55.74 \mathrm{qha}^{-1}$, respectively) compared to rest of genotypes.

\section{Harvest index (\%)}

Statistically sowing windows and genotypes both had significant effect on harvest index of wheat (Table 2). Harvest index during $45^{\text {th }}$ SMW (39.31\%) sown wheat was significantly higher than sown during $48^{\text {th }}$ SMW (37.56\%). Harvest index of genotype MACS 6478(40.58\%) was significant and which was followed by $\mathrm{GW}$ $322(40.42 \%)$ and MACS 6222(39.57\%).

Sowing windows had significant effect on growth parameters (days to heading, days to maturity, plant height, spikelets spike ${ }^{-1}$ except spike length) and yield attributing characters (effective tillers meter ${ }^{-2}$, grains spike $^{-1}$, harvest index except thousand grain weight, 
biomass and grain yield). Maximum number of effective tillers meter ${ }^{-2}$, grains spike ${ }^{-1}, 1000$ grain weight, biomass and grain yields were found with normal sowing window i.e. sown during $45^{\text {th }}$ SMW (5 to 11 November) compared to late sown wheat i.e. during $48^{\text {th }}$ SMW (26 November to $2^{\text {nd }}$ December). Genotypes had significant effect on all growth parameters except spikelets spike ${ }^{-1}$ and all yield attributing characters. Among genotypes, MACS 6478found superior with maximum spikelets spike ${ }^{-1}$, effective tillers meter $^{-2}$ and grain yield. The interaction of sowing windows and genotypes was significant over days to heading, days to maturity, plant height and grains spike ${ }^{1}$.Therefore, from above investigation it was concluded that normal sowing window i.e. during $45^{\text {th }}$ SMW (5 to $11^{\text {th }}$ November) was the most optimum time for wheat planting under peninsular zone.

\section{Acknowledgement}

Authors would like to express their gratitude to all the staff of the Genetics and Plant Breeding department; Agharkar Research Institute, Pune for providing facilities and ICAR-Indian Institute of Wheat and Barley Research, Karnal for providing fund for the study.

\section{References}

Ansary, A.H., Khushak, A.M., Sethar, M.A., Ariam, N.A. and Emon, M.Y.M. 1989. Effect of sowing dates on growth and yield of wheat cultivars. Pakistan Journal of Scientific and Industrial Research, 32: 39-42.

Aslam, M., Hussain, M., Akhtar, M., Cheema, M.S. and Ali, L.2003. Response of wheat varieties to sowing dates. Pakistan Journal of Agronomy, 2(4): 190-194.
CIMMYT. 2002. Wheat the vital grain of civilization and food security: wheat annual report. Mexico, DF.

Connor, D.J., Thiveyanathan, S. and Rimmington, G. M. 1992.Developement, growth, water-use and yield of a spring and winter wheat inresponse to time of sowing. Australian Journal of Agricultural Research, 43:493-506.

Dokuyucu, T., Akkaya, A. and Yigitoglu, D. 2004. The effect of different sowing dates ongrowing periods, yield and yield components of some bread wheat (Triticum aestivum L.) cultivars grown in the East-Mediterranean region of Turkey. Journal of Agronomy, 3(2): 126-130.

Donaldson, E., Schillinger, W.F. and Dofing, S. M. 2001. Straw production and grain yield relationship in winter wheat. Crop Science, 41:100-106.

Hossain, A., Islam, M.R., Rahman, KAMM, Rashid, M.H. and Anwari, A. 2017. Comparative performance of three wheat (Triticum aestivum L.) varieties under heat stress. International Journal of Natural and Social Sciences, 4(3):2642.

Khaliq, D. 2004. Modeling the growth, radiation use efficiency and yield of wheat under different sowing dates and varying nitrogen levels under rainfed conditions. M.Sc. (Hons.) Thesis, University of Agriculture, FaisalabadPakistan.

Marasini, D., Santosh, Marahatta, Surya, ManiDhungana and Ramesh, Acharya. 2016. Effect of sowing on yield and yield attributes of different wheat varieties under conventional tillage in sub-humid condition of Chitwan district of Nepal. International Journal of Applied Science and Biotechnology, 4(1):27-31. 
Matuz, J. and Aziz, J.S.1990. The effect of sowing season on Iraqi and Hungarian wheat varieties. Cereal Research Communication, 18 (1-2): 41-43.

Phadnawis, B.N. and Saini, A.D. 1992. Yield models in wheat based on sowing time and phenological developments. Annals of Plant Physiology, 6(1): 52-59.

Rajput, R.L. and Verma. 1994. Effect of sowing dates on the yield of different varieties of wheat in Chambal Command Area of Madhya Pradesh. Indian Journal Agronomy, 9:165-169.

Shahzad, K., Bakht, J., Shah, W.A., Shafi, M. and Jabeen, N. 2002. Yield and yield components of various wheat cultivars as affected by different sowing dates. Asian Journal of Plant Science, 1(5): 522-525.

Shahzad, M.A., Din, W.U., Sahi, S.T., Khan, Ehsanullah. M.M. and Ahmad, M. 2007.Effectof sowing dates and seed treatment on grain yield and quality of wheat. Pakistan Journal of Agriculture Science, 44 (4): 581-583.

Singh, D., Agarwal, R.L. and Ahuja, K.N. 1998. Response of wheat varieties to different seeding dates for agro-climatic conditions of Agra region. Annals of Agriculture Research, 19:496-498.

Spink, J.H., Semere, T., Sparkes, D.L., Whaley, J.M., Foulkers, M.J., Clare,
R.W. and Scott, R.K. 2000. Effect of sowing date on plant density of winter wheat. Annals of Applied Biology, 137:179-188.

Tahir, M., Asghar, Ali, Muhammad, Ather. Nadeem. Akhtar, Hussain and Farhan, Khalid. 2009. Effect of different sowing dates on growth and yield of wheat (Triticum aestivum L.) varieties in district Jhang, Pakistan. Department of Agronomy, University of Agriculture, Faisalabad-Pakistan. Pakistan Journal of life and social sciences, 7(1):66-69.

Vahid, Khosravi, Gholamraza, KhajoieNejad., Ghasem, Mohammadi-Nejad and Khatoon, Yousefi. 2010. The effect of different sowing dates on yield and yield components of wheat (Triticum aestivum L.) cultivars. International Journal of Agronomy and Plant Production, 1 (3), 77-82.

Wajid, Ali. Shah, Jehan, Bakht, Tehseen, Ullah., Abdul, WahabKhan., Muhammad, Zubair and Abdul, Aziz Khakwani. 2006. Effect of sowing dates on the yield and yield components of different wheat varieties. Journal of Agronomy, 5(1):106-110.

Wall P.P. 1991. Wheat crop management in warmer area: a review of issue and advances. Mexico: CIMMYT.

\section{How to cite this article:}

Bankar, D.N., V.S. Baviskar, K.J. Yashavantha Kumar, S.S. Raskar, S.S. Khairnar, V.D. Gite, V.D. Surve, J.H. Bagwan and Honrao, B.K. 2018. Evaluation of Wheat (Triticum aestivum L.) Genotypes for Changing Climatic Condition under Different Sowing Windows in Semi-Arid Tropics of Western Maharashtra. Int.J.Curr.Microbiol.App.Sci. 7(04): 761-770. doi: https://doi.org/10.20546/ijcmas.2018.704.085 